\title{
D \& H Management and D \& H Patio Homes: To Dream the Impossible Dream? Parts A \& B
}

\author{
Herbert Sherman \\ Brooklyn Campus - Long Island University \\ Daniel James Rowley \\ University of Northern Colorado
}

\begin{abstract}
This is a field-based disguised two-part case which describes the market and operation of a small conglomerate business, in the home rental and home construction markets. The immediate problem is how to make the operations profitable enough so that the managing partner can afford to start to take a salary from the business and leave his teaching position. Longer term, the partners need to address how they can make the businesses a source of income for their retirements. The case has a difficulty level appropriate for a senior level course in small business management, entrepreneurship, or strategic management.
\end{abstract}

\section{PART A}

It was June of 2006 and, although the sun was shining brightly, it seemed like another dark, dingy and downcast afternoon to Richard Davis as he drove up once again to DHR Patio Homes, LLC's work site. Richard, a college professor who had started a real estate management firm back in 2002 with his friend and colleague, Stephen Hodgetts, was serving as the contractor for the firm's home construction operations as well as the managing partner for their home rental business.

Richard chatted with several of the subcontractors and checked in with his foreman, James Kennison. He also turned from time to time to take in the picturesque snow covered mountains to the west. After Richard toured the work sight, he took another long look at the scenic view, made a very heavy sigh, got back into his SUV, and drove back towards his college campus.

While driving back, Richard reflected upon the past four years. "I should have retired from academia by now. I never thought that I would still be working at the college nearly four years after Stephen and I started our first business, the real estate rental company. That's not what we intended! I should not be working as the on-site contractor and rental manager as well as a full time faculty member; but what can I do? Our last three site managers met with little success and I don't have the cash flow that would allow the firm to pay me a decent wage so that I can give up my university paycheck. I've just about given up on my writing and research, that's what Hodgetts is doing for the both of us, and, as much as I still like teaching, I really would like to devote my full attention to the businesses. 
Davis thought back to how this whole business started as just a small home rental management firm and ballooned into a baby conglomerate including the original rental agency and a residential construction firm. (See Appendix A: History of D \& H Management and D \& H Patio Homes for details.) Davis's reflections then turned to the changes in the home construction industry and home rental markets over the past several years with him noting that what was a boom building market just a few years ago was clearly becoming a bust while the slumbering rental market was picking up steam. (See Appendix B: The Home Construction and Rental Markets.) After careful deliberation, Richard decided that he should sit down with Stephen and have them discuss their firms' overall situation.

\section{To Rent a Home or an Apartment or Buy a Home? That is the Question!}

Before their first meeting, Stephen reviewed Richard's research on the residential home construction industry and the rental markets and agreed with Richard that the overall economy did not seem favorable to home construction, especially for homes that were geared towards lower middle income buyers. They quickly agreed before the meeting that this population might be more inclined to rent for the next few years, however, the question was whether or not they would rent houses or merely apartments; this became the topic of their meeting.

Three bedroom apartments in more upscale apartment complexes would seem to be the most similar in size to the smaller homes they were renting (the homes were 12001400 square feet, had three bedrooms and two baths, some with finished basements adding about 800 square feet with two extra bedrooms, one bath, and additional family room), and their homes' rental prices seemed to be about $\$ 200 /$ month more than the rental apartments, higher by about 20 percent.

The advantages of renting an apartment over a small home was that the upkeep costs were far cheaper (heat, water, sewer, and garbage removal were usually included; electricity was far less expensive for an apartment than for a home), the apartment complex came with many amenities that were not available to the typical home owner (a pool, a gym, a club house, and private security), building and grounds were maintained by the apartment ownership, and there was a ready-made community with a strong potential for social interaction. The drawbacks, however, included limited privacy, less living space, no potential for home ownership, limited garage and storage space (at extra cost), and dealing with "professional" managers rather than small business owners.

After a lengthy discussion, Richard and Stephen concluded that these potential home renters were trying to climb to the next economic level, what they called "home owner wanna bes." They were those individuals who wanted to be associated with homeowners and considered themselves a class above the typical renter, yet could not afford, at least in the near term, home ownership. "They want the feel of a home, the look of a home, and the neighborhood and school system that comes with home ownership" Richard surmised. "They want the white picket fence around their 
beautifully manicured lawn, the American dream, but they do not have the financial wherewithal to pull it off." Richard and Stephen also deduced that as mortgage rates continued to rise, that there would be an increasing number of these type of renters, those caught between the desire for home ownership and the means to do so. After thinking about this for a long while, they realized that this type of renter could run the gamut from a young family to empty nesters, blue collar to lower level white collar workers, but they also assumed that DINKS (dual income, no kids) would be able to afford a home and not be a part of their rental target market since "DINKS are often the target of marketing efforts for luxury items such as expensive cars and vacations." (http://www.investopedia.com/terms/d/dinks.asp)

Davis and Hodgetts, however, thought that DINKS would be an excellent target market for their custom built patio homes since patio homes required less maintenance than a typical home and were in fashionable neighborhoods. These homes, although running upwards of 4500 square feet, were on no more than $1 / 2$ acre plots with lawn care, garbage disposal, and snow removal handled by their Home Owner's Association (HOA). The homes were part of a gated community which provided each homeowner membership in the local golf club and pool club, discounted meals and merchandise at the club house and pro shop, and numerous walking paths.

\section{The Other End of the Market Channel: Suppliers}

Their discussion quickly shifted from customers to suppliers. Large suppliers (like 84 Lumber, Home Depot, and Loews) carried enormous stock and usually had very good prices and easy financing. However, they tended not to carry more upscale items in areas such as cabinetry, plumbing fixtures, tiles, and flooring. More importantly, as a small business owner, Davis found that he had very little pull with their service and billing departments when there were shipping errors or special orders. Material would be left at the site even if there was no one there to receive it. This lead to both missing inventory (or theft) and a lack of verification of goods delivered. On several occasions orders had been shipped to the wrong address or they were inaccurately billed. Davis was most frustrated at these firms' lack of responsiveness to his problems.

Local suppliers, although they did not always carry the material Davis needed, had much better service in that they could have his material shipped to the building site in just a couple of days. The national chains offered enough competition to the locals so that the locals had to keep their prices competitive. As a result, Davis felt he got the best of both worlds; a good price with excellent service. As fellow small business owners, they tried to woo his business through competitive pricing and personalized attention.

Davis and Hodgetts then revisited Davis's calculations of home construction costs. It seemed that Davis made the assumption that operating costs would remain about the same or at least in line with inflation over the life of their building project. This assumption was predicated upon the fact that a slow down in the construction industry would reduce demand on building supplies (lumber, concrete, tile, electrical, HVAC, 
etc...) which would increase competition amongst large chain suppliers, as well as local, unaffiliated suppliers.

However, Davis and Hodgetts were also aware of an article that Hodgetts had read and shared with Davis that projected that the vast destruction caused by hurricanes Katrina and Rita was expected to push up costs across the construction industry because of a tighter market for materials and labor. The report projected price increases nationally, as a result of the storms and the oil price hikes, to reach 20 percent for steel, 15 to 20 percent for gypsum, 20 percent for dimensional lumber, and 30 percent for panel products. Overall, the report projected storm-derived construction cost increases over the next two years of 5 to 10 percent nationally for residential construction. (Padalka, 2005) Yet another article that Davis read and shared with Hodgetts noted that most of the increased costs in construction materials throughout the country would result from a reduction in oil and natural gas production, and not from higher demand for those materials for the reconstruction projects in the devastated areas. (Schultz, 2005)

The slowdown in sales in their area meant that Davis and Hodgetts would have to absorb any increased construction costs although they hoped that suppliers might soak up some of those costs due to reduced demand and increased competition. In the interim, they decided not to raise their prices and to monitor construction costs.

Richard Davis and Stephen Hodgetts felt that they left their meeting with a better understanding of their marketplace and their suppliers and decided that their next meeting would address some of the other elements in their business environment.

\section{Local Market Forces}

At their second meeting, the topic shifted to the local market.

Stephen: Let's first talk about what is happening locally in our area and how we are being impacted by local political, social, and environmental forces.

Richard: Ok - first off, we have had our share of problems with the local building inspectors. There seems to be a crackdown of sorts on builders in the area and the inspectors are getting overly picky about our meeting regulations to the letter of the law.

Stephen: What do you mean? Could you give me an example?

Richard: Sure thing. We just had a framing inspection on 411 and the inspector became incensed that we had accidentally had some of the rooms insulated, thereby covering some of the framing. Rather than letting us take down the few sections of insulation, which would have taken us maybe ten minutes, he failed us on the spot. When he came back the next time to do the inspection, and by the way we get charged for every inspection, he failed us because he felt that the metal brackets we used to hold in our 2' by 6' beams were not up to specifications. Now, these are the same brackets we have used in our other homes, no different than the rest. So I called Milt, 
the head of our local real estate professional association. He told me that the inspectors are taking a more hard-line approach now with all of the builders.

Stephen: But why? What has changed?

Richard: Good question. It seems that the town board has been getting pressure from local community environmentalists and local tax relief associations that believe that the area is becoming overbuilt and this building is negatively impacting the community. According to them, we're losing our small town feel while eliminating any open spaces, creating congestion and pollution, while simultaneously raising the real estate tax rate needed to expand services, mostly educational, to new homeowners. The short run solution, it seems, is to strictly enforce all building codes, in fact, to perhaps go overboard a little, and to try to slow down those homes that have already been approved for development.

Stephen: And the long-run solution?

Richard: There has actually been talk of a 90 to 180 day building moratorium (a moratorium would block the approval of any new home construction; existing construction would continue.) so that the town could hire a consultant to conduct research and examine the zoning laws as well as the impact of continued residential construction on community services. (Miller and Aaron, 2004) Of course we builders, with our local real estate professional association, would try to stop the moratorium, since we believe that these moratoriums are unfair and actually lead to greater development sprawl in the long run. (The Dynamics of Building Moratoriums, 2003) Builders have, at times, been successful through legal action in stopping these moratoriums but we would have to hire a lawyer, meaning additional legal expenses. (Pennsylvania Builders Assoc. Reacts Court Decision on Building Moratoriums, 2001; Pilgrim, 2004)

Stephen: So what do you think will actually happen?

Richard: My best guess is that we builders will put pressure on the town board. Local civic and tax groups will do the same, and the local politicos will probably rule in favor of the most vocal group who can vote them back into office. We'll of course, through our professional association, donate money to their election campaigns while trying to work with the politicians and local community groups to reach a compromise. Hopefully we can avoid a moratorium, or at best have such a short one (i.e. 90 days) that will not negatively impact our businesses. The real battle will come when and if there are any proposals to change zoning laws, for example, requiring a larger amount of property per home or restrictions on size or types of homes being built. This is all speculation on my part and we'll cross that bridge when we come to it.

Stephen: I see, getting back to the inspectors, how are you handling their increasing vigilance? 
Richard: You're being politically correct, although inaccurate, with the term vigilance, they're becoming zealots! However, with the building boom still underway, these inspectors are stretched to their limits. (Ramirez, 2005) Given the great demands placed upon them, I really do not know if they can afford to be overly strict when enforcing the building codes and perhaps, because of workload, will become a little more realistic in their demands. In the interim, we are taking extra care in terms of making sure we exceed, if not meet, code requirements. Since the industry, like us, has a bit of a work slowdown, our subcontractors have the time to take the extra care needed to surpass code. We're also doing our own on-site inspections so that any obvious flaws are handled before the inspector ever gets to the site.

\section{Local Subcontractors}

Stephen: You mentioned our subcontractors, what is going on with them?

Richard: As you know, we subcontract out all of our work with James Kennison serving as our on-site coordinator, also acting as a subcontractor. I've taken back the job of contractor but use Jim to keep an eye on things and to provide additional manpower when needed. Jim's been doing these pre-inspections for us and he has also become a finisher, coming in after the subs are finished with their work and doing any final touch up that is needed to pass inspections or getting the subs back to fix any problems he cannot.

Since we have an industry slowdown, the problems we used to have with our subs, getting them to do their work in a timely manner, has lessened since they are now not as overloaded. On the other hand, our subs have had to take on far more clients and as a result it is quite possible that our work may not be given the same priority it has been in the past. I have tried to offset this problem by lining up at least two backup subs for each job our current subs do - this has actually worked out quite well in that the backup subs see this as an opportunity to pick up some unexpected work and to demonstrate how good they are. All the subs know that as the industry slows down that there will be less work for them to do and that there will be greater competition amongst themselves. Those subs who have locked in strong relationships with contractors, contractors who will continue to build homes that is, will survive the upcoming work drought.

\section{Local Competition}

Stephen: That gets us into competition - what is happening there?

Richard: An excellent question once again. Our competitors fall into three categories: national home builders, like D.R Horton and K.B. Homes, manufactured homes, and local "family" firms. Hoovers reported that "Despite the economic slowdown, large homebuilders such as Lennar, Pulte, and Centex are toasting record-breaking increases in sales and profits, and stand to fare every bit as well in the foreseeable future. Thanks to the prolonged and steady drop in 30-year fixed mortgage interest rates - from 
around 7 percent in mid-2001 to around 5.5 percent by mid-2003 (a rate which hasn't been seen since the late 1950s and early 1960s) - residential construction companies, as a whole, have been insulated from a generally dismal economy and stock market. ... Most of the large residential homebuilders act more as general contractors than builders. They don't have the overhead that many builders carry. And many homebuilders don't think their market is likely to shrink soon. Most have focused their businesses on demographic trends that seem to be unstoppable: They're building in the South to accommodate sun seekers and growing Latino communities and adding active-adult communities to cater to the graying of America's baby boomers." (Sarath, P., n.d.)

On the other hand, "the manufactured housing industry - essentially builders of homes on wheels - has been suffering through its toughest time since it emerged from the RV industry in the 1960s. After a decade of unprecedented growth during the early- and mid-1990s, the largest manufactured homebuilders - Clayton Homes, Champion Enterprises, and Fleetwood Enterprises -- have seen revenues and profits decline and/disappear. ... The industry - intoxicated by the potential of more double-digit growth - grew too fast, outpacing demand to such a degree that the necessary correction has been, and may continue to be, painful." (Sarath, P., n.d.)

Surprisingly, 70 percent of the builders in the U.S. are like us, they build less than 25 homes a year. (http://www.nahb.org/page.aspx/category/sectionID=563) However, it has been projected that small home builders will shrink and only represent 50 percent of the market since "bigger builders are looking to diversify by acquiring smaller builders who specialize in second homes, adult communities, etc., or for access to their land." (Miodonski, n. d.) As you know, these larger firms have a lower cost of capital than us small firms since they can not only borrow at lower lending rates but can also raise capital through stock sales or issue corporate bonds. These larger firms also have greater economies of scale in that they can purchase raw material and property in bulk.

However, "giant home builder firms tend to be bureaucratic instead of entrepreneurial, are more risk averse, must maintain large land inventories and often look toward shortterm results to satisfy the quarterly earnings demanded by Wall Street. ... Large builders have to feed the beast and many can be found sitting on an inventory of 7-10 years. If the market slows, they will be forced to get rid of the land, which may present an opportunity for small builders. It's up to the small builders to utilize better inside information on their home markets, and establish relationships with land owners." (Smaller Builders Can Compete Against Giants, 2006)

Stephen: Okay - so we might have a chance against bigger builders like Best Homes and KB or, if we're lucky, be made an offer we can't refuse to get out of the business. What about competition amongst our local small residential home builders?

Richard: Having talked with other local small builders, I can tell you that all of them are into slowdown mode, especially those building starter homes (3 bedroom, 2 bath). Assuming I can trust what our fellow builders are telling us, they're all in about the same 
shape that we're in. They're strapped for cash, sitting on empty speculation (a home that is built without an existing buyer) and model homes, and trying to build only on demand. None of them have yet dropped their prices but I think a few are adding amenities to their homes, like a second fireplace and Jacuzzi tubs, in order to increase the perceived value of their homes. This is especially true in our market, custom patio homes, where the price of these homes really does not vary by more than 5 percent (about $\$ 20,000$ ), but what a homeowner gets in that home may vary dramatically. For example, our model homes all include tile or slate roofs, wine cellars, and home theatre systems, real extras, yet we do not include central vacuum nor have we installed the extreme top of the line of kitchen appliances like Subzero refrigerators or LG washers and dryers. We have tried to differentiate ourselves from our competitors using our unique designs but these designs can be easily copied.

Stephen: Not exactly splendid news. Let me digest all of this since we've covered a lot today and let's take a break, think more about our marketplace, and then let's talk about the firms' marketing, finances, and other operational issues at our next meeting. 


\section{Appendix A \\ History of D \& H Management and D \& H Patio Homes}

(Modified from Sherman and Rowley, 2006)

The First Business - D \& H Management

In August 2002, when the Dow Jones Industrial Average dipped under 8000, Richard Davis and Stephen Hodgetts, academics, friends and coauthors, were lamenting their ever shrinking retirement funds. Neither were getting any richer on a faculty member's salary nor expected any windfalls from relatives, their book sales, or lottery tickets. As Hodgetts was fond of saying "America believes in education: the average professor earns more money in a year than a professional athlete earns in a whole week." (http://www.quotationspage.com/search.php3)

After a long discussion, they decided that they could not longer bear "the slings and arrows of outrageous fortune" and consequently needed to become masters of their own economic fate. They specifically wanted to increase their personal wealth to a point that they could retire. For Davis, that meant leaving the academy in a two to three years, becoming semi-retired, and perhaps working whatever business venture they concocted. For Hodgetts, that meant amassing enough wealth in the next 10-15 years so he could build his dream castle.

Davis had done enough preliminary research on the real estate market in their area and convinced Hodgetts (who had a bad experience renting his house several summers ago) that there was money to be made becoming what Hodgetts half jokingly called "slum lords." Davis and Hodgetts, with the assistance of Davis's real estate agent, found six families in three months and worked with these families to find them homes in the $\$ 175,000$ price range that the families would be happy to lease from Davis and Hodgetts and eventually purchase. The deal was so attractive that they even had a waiting list of new tenants. The six homes though had gobbled up their initial investment of $\$ 100,000$ and required an additional $\$ 80,000$ (which Hodgetts loaned the company); luckily their monthly cash flow yielded a net profit of $\$ 1,500 /$ month.

\section{Second Business - DHR Construction}

The construction company started off as just a small capital raising venture. Hodgetts and Davis would finish off the basements of their rental homes, get the homes reappraised, and then re-mortgage the properties pulling out an additional $\$ 10,000$ $\$ 20,000$ per home. These funds could then be used as down payments for future rental homes.

In chatting about this matter with some of their renters, Davis and Hodgetts were approached by one of their renters to perform all of the non-licensed work (excluding electrical, plumbing, HVAC, etc...) in order to finish off all of the other basements of their tenants. Davis explained to the renters (Alan and Wilma Bronson) that they would have to form their own LLC and act as any other subcontractor. After completing a few 
basements, Alan and Wilma enjoyed working on these basements so much that they approached Davis and Hodgetts about figuring out a way that Davis and Hodgetts could keep them occupied all year round - in essence, Alan wanted to quit his job and come work for David and Hodgetts. However, there was nothing that Davis and Hodgetts could do for Alan and Wilma at that time. Yet a few days later the situation dramatically changed.

One of Davis' students, David Russ, who was designing their basements, said that he thought that Davis and Hodgetts could cut out the middle man in terms of the rental business if they built their own homes. Davis thought that Russ was crazy at the time but they talked after class and Russ said that he would be happy to act as the general contractor and that he knew all of the subcontractors who were needed in order to construct new homes. Alan and Wilma would do all of the interior work, and Alan could hire some part-time workers to help out. In any event, Davis and Hodgetts could build the rest of their homes under a different company name, sell it to themselves for a profit, and then make a profit renting the homes. On a $\$ 150,000$ home Davis and Hodgetts would net about a 20 percent profit.

The profit derived from their construction operation lead Davis and Hodgetts to build homes not only to be purchased by D \& H Management as possible rental units but also for public consumption. In May, 2003 DHR Construction broke ground on their first home to be sold to the public in the St. Andrews development.

On November of 2003 Davis and Hodgetts bought out David Russ's interests in DHR Construction due to differences in management and business philosophies. Davis was left to act as contractor and by January 2004 they had completed three homes at St. Andrews. Alan quickly took over that role of foreman/contractor when DHR shifted their building site to another location, the Florence Development, which had a more upscaled look. By April of 2004 DHR had built three homes in Florence, had plans to build five more in that area, and were looking at other developments for future growth and expansion. On April 12, 2004 the Florence Development Corporation however did not pay their landscapers and each of the properties that were owned by Davis and Hodgetts in the development had a mechanic's lien placed on it for $\$ 450,000$. These properties were eventually sold to their third company, D \& H Patio Homes, and then immediately thereafter they closed DHR Construction.

\section{Third Business - D \& H Patio Homes}

While a deal was being brokered to try to clear Davis and Hodgetts' liens on the properties in the Florence Development, Davis in June of 2004 had located a brand new development about 10 miles east of where they currently were building, in an area called Snowy Mountains. Snowy Mountains was a unique project for the area since the developers had built lakes, a golf course, and club house (including a three star restaurant) and had very specific designs for community development. The housing currently in the development (phase one) ran the gamut of homes, from two bedroom 
condominiums (that started around $\$ 140,000$ ) to multimillion dollar estate homes on the lake.

D \& H Patio Homes, LLC was established in August of 2004 by Richard Davis and Stephen Hodgetts in order to separate their construction projects in Florence (run under the corporate name of DHR Construction, LLC) from their latest project, Mountain Trails. Richard Davis acted as the architect and head of operations of construction while Alan would act as foreman and work with Richard Davis by helping to coordinate the subcontractors as well as continue his own subcontracting work dealing with wall hanging, lining, spackling, molding, and painting.

All was going well until Davis and Hodgetts were forced to change accountants. The new accountant found that Alan had accrued about $\$ 29,000$ of expenses that could not be accounted for or had questionable receipts and expenses. Alan was replaced, first by Richard's daughter, but that quickly turned into a disaster when with the subcontractors refused to work with her and she was sexually harassed by one of the construction workers. She was replaced by one of the subcontractors, James Kennison, but Kennison's mild mannered, laid back approach did not seem to work well enough to keep the construction work on schedule. Davis was forced to step back into the role of contractor, with Kennison serving as his eyes and ears at the work site. 


\section{Appendix B The Home Construction and Rental Markets}

The Federal Reserve's Beige Book Report on residential real estate (June 14, 2006) noted that:

Residential real estate markets continued to cool across much of the country--with most Districts reporting slower homebuilding and sales of existing homes. ... Some softening of the market for existing homes was reported by ten Districts--Chicago, Cleveland, Dallas, Kansas City, Philadelphia, Minneapolis, New York, Richmond, St. Louis, and San Francisco. Dallas and Richmond noted that activity remained quite strong, and Chicago reported slowing from high levels. San Francisco reports hot housing markets in Utah and parts of the Pacific Northwest. Several Districts said sales had weakened for some of the most expensive homes, except in the Dallas District where demand for lower-priced homes "had dipped noticeably." Atlanta reported that residential sales were near year-ago levels in most parts of the District, but that sales weakened and inventories increased in Florida. The Philadelphia District said sales of homes in resort areas have declined sharply. The New York District reports a sharp deceleration in prices in the suburbs around New York City, but a tightening of the Manhattan rental markets.

Homebuilding slowed in most Districts--Chicago, Cleveland, Dallas, Kansas City, New York, Philadelphia, St. Louis, and San Francisco. The New York District reported that some homebuilders in New Jersey are withdrawing from the authorization process and allowing their options to build to expire, noting that increases in fuel and materials costs are pinching profits. Homebuilders in the Atlanta District reported that single-family home construction was near year-ago levels in most parts of the District, except in Florida, where sales slowed. The Atlanta District also reported that Florida condominium sales continued to weaken and several projects were cancelled.

Residential construction spending, as reported by the U.S Department of Commerce, was up 2.4 percent from last year (May 2005 - May 2006) but was down 1.8 percent from its March 2006 high. Housing starts were up from April to May in 2006 by 5 percent but down from May of 2005 by 3.8 percent. (http://interactive.wsj.com/edition/ resources/documents/bbcon.pdf; http://interactive.wsj.com/edition/resources/ documents/bbstart.pdf)

The Federal Reserve continued to increase the Federal Funds Rate from 1 percent back in June of 2003 to 5.25 percent as of June of 2006. The Federal Reserve had not as yet signaled that their last rate increase was a final one and many economists believed that the Federal Reserve was apt to increase the rate at least a quarter point more. (Miller, June 30, 2006) This impacted home mortgages, raising 30 year fixed home mortgage rates from 5.43 percent (June of 2003) to 6.83 percent (June of 2006) and one year adjustable variable rates from 3.75 percent (June of 2003) to 6.08 percent (June of 2006). Although unemployment remained steady at 4.6 percent (June 2006), 
down from 6.3 percent in July of 2003 , the annualized consumer price index, as of May 2006, was up 4.2 percent while annualized personal income for the same period rose 5.5 percent. (http://www.hsh.com/mtghst.html; http://interactive.wsj.com/edition/ resources/documents/bbemp.pdf; http://interactive. wsj.com/edition/resources/ documents/bbcpi.pdf; http://interactive.wsj.com/edition/ resources/ documents/bbpi.pdf)

Personal bankruptcy rates, although skewed by the new regulations that went into effect in October of 2005 making it more difficult to qualify for bankruptcy, soared from the average monthly filing rate of 130,183 in 2004 to nearly 500,000 in March of 2006. Many analysts attributed this increase in personal bankruptcy to the increases in homeowners' adjustable rate mortgage payments. (Bankruptcy Filings Up Despite Reforms, 2006). Furthermore, "in January [2006], 103,540 homes were in foreclosure, up 27 percent from 81,290 in December and 45 percent above last year. January's foreclosure total was the highest level since RealtyTrac began releasing monthly reports in May 2005. ... January's 27 percent increase in foreclosures is consistent with the increasing foreclosure trend seen throughout 2005 . In total, nearly 847,000 properties entered foreclosure in 2005 , representing 0.7 percent of total households." (http:// bigpicture.typepad.com/comments/2006/02/home_foreclosur.html) "For housing market watchers, a unifying understanding of the economy in the near term was not established last week [July 3,2006] and the uncertainty will continue to chip away at housing consumer confidence, whether its justified or not." (Miller, July 10, 2006)

\section{Rental Properties}

"With the price of residential properties continuing to rise in most markets across the U.S. first time buyers \{are\} now looking for rental homes as a fix until markets correct themselves. ... With the price of homes up about 10-15 percent over the last 12 months and more than 55 percent nationwide over the last five years, many hopeful low- and middle-income buyers are increasingly turning to rental properties, both multifamily and apartments, as their primary choice for shelter.

.... According to the results of the National Association of Home Builders/Fannie Mae Multifamily Housing Market Index (MMI), rising occupancies and rental rates pointed to increased consumer demand in rental homes. ...current demand saw both moderately priced (Class B) and lower-rent apartments (Class C) reaching their highest levels ever in the first quarter of 2006, with moderately priced units topping the index at 71.4, up from 60.6 at the same time last year and about 30 points higher than the last quarter of 2002." (Mosca, 2006) 


\section{References}

Miller, A. and Aaron, K. (July 5, 2004). Towns Struggle to Slow Growth. Albany, N.Y.: Times Union, A3.

Miller, J. J. (June 30, 2006). FOMC Makes it 17 at 5.25percent and Seems to Get it About Housing. Retrieved from http://matrix.millersamuel.com/?p=723, July 10, 2006.

Miller, J.J. (July 10, 2006). Jobs Up, Jobs Down, Confusion All Around. Retrieved from http://matrix.miller samuel.com/?cat=6, July 10, 2006.

Miodonski, B. (n. d.) Nation's Biggest Builders Will Polarize Housing Market. Retrieved from http://www. contractormag.com/articles/newsarticle.cfm?newsid=646, July 17, 2006.

Mosca, P. (2006). Priced-Out Buyers Push Occupancy Rates and Apartment Builders' Confidence Higher. Retrieved from http://realtytimes. com/rtcpages/ 20060705_ pricedout.htm, July 10, 2006.

Padalka, A. (2005). Construction Costs. New York Construction 53(5), 142.

Pilgrim, J. (January 30, 2004). MORATORIUMS: Builders Let Board Have It, Halt to Construction Protested at Hearing. East Hampton, New York: The East Hampton Star, A1.

Ramirez, C. (August 9, 2005). Building Boom Tests Inspectors. Retrieved from http://www.azcentral.com/ community/gilbert/articles/0809GR-InspectZ12.html, July 17, 2006.

Sarath, P. (n.d.). Residential Construction. Retrieved from http://premium.hoovers.com/ subscribe/ind/overview.xhtml?HICID=1154, July 17, 2006.

Schultz, B. (2005). Hurricanes Blow In Higher Construction Costs. Equipment Today 41(11), 6.

Sherman, H. and D. J. Rowley (2006). The Reluctant Manager. Journal of Behavioral and Applied Management 7(3), 320-329.

(June 12, 2006). Bankruptcy Filings Up Despite Reforms. Retrieved from http://money .cnn.com /2006/06/12/pf/personal_bankruptcy.reut/?section=money_pf, July 10, 2006.

(July 27, 2001). Pennsylvania Builders Assoc. Reacts Court Decision on Building Moratoriums. Retrieved from http://rockproducts.com/news/rock_pennsylvania_ builders_assoc/index.html, July 17, 2006. 
(January 30, 2006). Smaller Builders Can Compete Against Giants. Retrieved from http://www. nahb.org news_details.aspx?sectionID=766\&newsID=1903, July 17, 2006.

(November 18, 2003). The Dynamics of Building Moratoriums. Retrieved from http://www. planetizen.com/ node/11687, July 17, 2006.

http://bigpicture.typepad.com/comments/2006/02/home_foreclosur.html, July 10, 2006. http://interactive.wsj.com/edition/resources/documents/bbbeige.htm, July 10, 2006. http://interactive.wsj.com/edition/resources/documents/bbcon.pdf, July 10, 2006. http://interactive.wsj.com/edition/resources/documents/bbcpi.pdf, July 10, 2006. http://interactive.wsj.com/edition/resources/documents/bbemp.pdf, July 10, 2006. http://interactive.wsj.com/edition/resources/documents/bbpi.pdf, July 10, 2006. http://interactive.wsj.com/edition/resources/documents/bbstart.pdf, July 10, 2006. http://www.hsh.com/mtghst.html, July 10, 2006.

http://www.investopedia.com/terms/d/dinks.asp, July 11, 2006.

http://www.nahb.org/page.aspx/category/sectionID=563, July 17, 2006.

http://www.quotationspage.com/search.php3, August 27, 2003. 


\section{D \& H Management and D \& H Patio Homes: To Dream the Impossible Dream? Part B}

It was only a few days after Stephen Hodgetts's and Richard Davis's last meeting and Richard decided to immediately address the firm's financial situation with Stephen.

\section{The Rental Business}

Richard: D \& H Management currently owns thirteen homes, eight of those homes located within the St. Andrews development and the other five in Florence. The values of these homes are estimated to be approximately \$ 3.6 million dollars (less depreciation) with outstanding loans slightly less than the values of the homes. We are fully leveraged with these properties and have little borrowing capacity. (See Exhibit $1 \mathrm{D}$ \& H Management Balance Sheet, 5/31/06.) These properties should generate a total monthly revenue stream of about $\$ 25,000$. Expenses for these homes usually run around $\$ 23,000$ a month, predominately mortgage payments, so in theory we net $\$ 2000 /$ month or about a little over 8 percent profit. (See Exhibit 2 D \& H Management Income Statement, 5/31/06.)

Stephen: Wait a minute, you said "should generate." What is actually happening?

Richard: That's an interesting query. In reality we have had vacancies in several of our homes, some due to lack of renters, others due to the fact that we have put some of our homes on the market to be sold. Homes show better when they are staged (they have furniture) but are not occupied. We have also had damage by former renters where the damage was beyond their monthly security deposit. In several cases we have gone to small claims court against these renters but most of them do not show up. We have won judgments against them yet, with no forwarding address, have little to no way to enforce those judgments. The cost of hiring someone to chase these deadbeats is usually greater than the amount we've been awarded.

Furthermore, since many of our mortgages are on variable interest rates, our mortgage payments have also climbed in the past few years. I estimate that our mortgage payments have gone up at least 20 percent over that time period, considering, at one point, our variable rate mortgages were at 4 percent and now they're around 6 percent. Rents have certainly not climbed accordingly and we have been fortunate in just being able to maintain our rent revenues at our current levels. Luckily, our newer mortgages provide us the option of making interest only payments, or, a lower 1 percent interest payment where the difference between interest only and the 1 percent is added to our base loan. We have yet to use either option although these options do provide us with a potential means of leveraging even more cash out of our properties.

Right now we have only two vacancies out of thirteen homes, about an 85 percent occupancy rate, thanks in great part to our new real estate agent's ability to find us quality renters who are serious about eventually purchasing these properties - but you can never tell with renters what will happen! As you know we have had several 
evictions over the last few years and I would not be at all surprised if we are forced to evict another tenant or two in the upcoming years. Being a landlord has been a lot tougher that I could have imagined and a downward economy has not helped us, at least in the short run.

Stephen: I thought we were also trying to sell these properties as well?

Richard: That's right. We agreed to sell $1 / 2$ of our inventory and try to shrink our rental operation to six units - a number we believe is far more manageable. However, with the downturn in the residential home market and our net negative cash flow with our rental units, I don't know if it is worth keeping any of these homes off the rental market. Given my research, we may find that the rental market comes back because home ownership has been priced out of reach of many consumers.

The great thing about these rental units, assuming we can achieve 100 percent occupancy, is that we would then generate a positive cash flow while still having a possible loss due to building depreciation. Since we're a LLC, these losses pass through the corporation and go directly to our personal income taxes. If you recall, last year the losses in $D$ \& $H$ Management were more than enough to cover the profits from D \& H Patio Homes."

\section{The Construction Business}

Stephen: Sounds good, what is happening with the Florence Development, if anything?

Richard: Glad you asked. You know that we still have four vacant lots that are worth about $\$ 270,000$ (See Exhibit 3 D \& H Patio Balance Sheet 5/31/06) in that area and that we have had them up for sale for the past six months. We're taking a beating because we're still paying the loan interest on these properties. There still seems to be very little consumer attention in the area since we cleared up the lien on these properties caused by the developer going chapter 11 . Bessler Homes did come back to the development and has built about forty homes in the area, yet only two units have sold and the rest are standing unoccupied. The development looks like a ghost town and I am not at all optimistic that our properties will be sold or be built on anytime soon. We also took a loss on DHR Construction when we closed down the firm, and as a LLC, these losses again passed through to our taxes. The properties are now owned by D \& H Patio Homes.

Stephen: Well - at least there is some good coming out of this disaster. Looks like Uncle Sam will be paying us back lots of tax money this year.

Richard: I wouldn't spend the money just yet. The good news, or perhaps a better way of saying it is the better than the other news is what is happening at Snowy Mountain. We've built about ten homes, have two in-process, and it looks like we will have whittled our major land loan down to about $\$ 600,000$. That will leave us twenty interior lots that we can build on since the lakeside lots are all spoken for. I think the lots are worth 
about $\$ 70,000$ a piece so if we just sold nine, even without building, we'd be out of the loan. Any profit from that operation would then be used to pay off the loans on the Florence properties, any current liabilities, and to finance our own construction rather than to take on more building loans.

Stephen: Sounds good to me - what is the down side?

Richard: Well, sales have really slowed down over the winter. We've gone from selling two homes a month to barely one a month. With Phase II of the Snowy Mountain development well underway, many people want to buy into a new development rather than buy the dregs from the old one. Paying off the land debt has put a real crimp on our cash flow, as well as the fact that this firm has lent our other firm money in order to solve their cash flow problems, and we've made a profit with little liquidity to show for it. Luckily, this profit of about $\$ 75,000$ (see Exhibit $4 \mathrm{D} \& \mathrm{H}$ Patio Income Statement $5 / 31 / 06$ ) will be partially offset by our losses from D \& H Management, about $\$ 20,000$, leaving us a shared tax liability of $\$ 50,000$. With the slowdown in business, however, I expect that we'll have less profit by the end of the fiscal year for $D \& R$ and probably a greater loss for $D \& H$. At best, I would expect a wash between the profits of $D \& R$ and the losses of $D \& H$.

Stephen: I guess I just lost my April $15^{\text {th }}$ bonus. I gather that your retirement has been put off as well as your management fee.

Richard: You're unfortunately correct. I can't afford to pay myself for the time I spend working on these firms although I have saved some money for the firms taking over as the contractor. As you must certainly have noticed, I haven't stiffed any of our suppliers yet and I don't intend to - I'll pay us both when I see cash flow increasing.

Stephen: That's not going to help either of us if we're not getting some benefit from operating these firms.

\section{The Big Picture}

Richard: Well in a way, we are. D \& H Management is sitting on about $\$ 3.6$ million of property which is fully leveraged. Once we pay down the loans using rental income, we will be sitting on a nice set of assets. These houses may be depreciating on the books but property values still seem to be climbing at about 5 percent per year. We'll see if this trend continues in the future given the slow down in construction. Historically, we have taken out second mortgages on these homes to further leverage them for cash flow purposes but we shouldn't need to do that if our units are all rented.

D \& H Patio has about $\$ 2.8$ million in property with about $\$ 2.7$ million in liabilities, again, once the construction loans get paid off, $\$ 1.3$ million, and the property loans of about $\$ 750,000$, we could be sitting on 11 properties free and clear in Snowy Mountain, worth about $\$ 770,000$. Add that to the Florence properties and we'll have another $\$ 270,000$ in 
assets, about $\$ 1$ million. Our only liabilities on these properties would be taxes. Not bad for our efforts, I must say.

Stephen: I don't mean to be disrespectful, but that sounds like a lot of wishful thinking, hoping, and praying. If that is our upside, then what is our down side?

Richard: Why Stephen, that's easy. Our down side is that we're stuck with about $\$ 6.3$ million in liabilities between our two firms, and not enough cash flow to pay the mortgages. At that point we'll either have to dig into our own pockets and loan ourselves some money, borrow more money from the bank or a venture capitalist, sell the firms (presumably at a loss), have a fire sale and sell off some of our properties at huge losses, or go out of business and be personally responsible for the loans since that the banks would only loan us the money if we were held personally liable. You've always complained that you didn't like your house anyway, so what are you worried about if the banks take it as part of a foreclosure?

Stephen: You're just Mr. Sunshine, aren't you? Any other bad news? You know how I love to hear dismay and despair.

Richard: Not at the moment. Let's meet next week and pick up this conversation where we left off. I still feel we have a lot to cover yet but I don't want to rush over things.

Stephen: Fine. We'll have a meeting next week and then our normal meeting the week after.

\section{Marketing}

Their next meeting was an interesting one since their vacant rental units had just been leased and, with a change in real estate agents, there was more traffic going through their newly constructed patio homes. Both Stephen and Richard were in a more upbeat mood and it was hoped that they might actually see some light at the end of the proverbial tunnel in terms of the businesses turning a corner and making a profit.

Stephen: Ok - let's see if we can run through a discussion of how we market and run the businesses and see if there is room for improvement. I always feel like an outsider looking in since I'm quite preoccupied with our writing and research projects. Where would you like to start?

Richard: Well, let's start with marketing. We have received some publicity for our homes through our developer, Snowy Mountain. They feature our homes on their website and in their advertisements; however we have really never seen any business referrals from this. This has meant that we have heavily relied upon our real estate agent, who operates on a six percent commission, in order to obtain potential purchasers for our homes. These homes and vacant properties have been advertised 
in the multiple listings but as you also know this has lead to no sales and limited showings of our homes.

Stephen: Yes - ironically, we have sold all of our homes so far through our own network of friends or to our own business. These purchases have been predominately for investment purposes and to people who are already living in the development and wanted a more upscale home or to people who had friends and family in the development and want to live near them. We've saved on the commission this way but our real estate agent has been a real bust in this regard.

Richard: I know, it has been very frustrating. Well, we have gone through several real estate agents, both for our rental units and for our home sales, and I think I have finally found one agent who is great for getting us renters and a second agent that really seems to understand the home patio market. Rhonda, our home rental agent, gets a one month rental fee from us for each home she rents and her services include qualifying renters (doing a credit and background check), advertising the rental homes, doing a walk through, and handling the lease paperwork. She has taken pictures of the interior of our rental homes and put them on her rental web site, allowing people to take a virtual tour.

More importantly, she seems to have a very good sense of getting us renters who want to eventually buy their homes, and, renters who will not physically abuse our properties and who will pay their rent in a timely fashion. Several of her renters, however, are 'betweeners' - they're building a home or waiting for their own home which they have purchased to become vacant so that they can eventually move in. These are one year renters - not the plan we originally had in mind for three year leases with options to buy, but they fill our homes, pay on time, and take good care of our homes.

Stephen: Ok - so the rental side of the business seems to have stabilized although I assume that we'll have more turnover in renters given the fact that more of our renters are in for the short term. What about on the home sales side of the house?

Richard: Our new agent, Bob, for our patio homes, has a very different perspective on our homes and the market. Historically, we and our sales agents have defined our target population as those people living within a 100 mile radius of the area. It seems, from what Bob is telling me, that the "locals" are not interested in Snowy Mountain or any other development in the area. If they are looking for a nicer home they are also willing to travel, that is move, in order to be in a new neighborhood and a new region.

Stephen: So what Bob is saying is that people who want the type of home that we build who live in our area would rather move out of the area to live in a similar development? That sounds crazy - how does he know this?

Richard: Bob's information, it seems, has been gathered from focus groups that he and his agency run every month in order to get a better feel for the local market. They also 
tract hits on their web site, property inquiries, local sales, new construction applications, and interestingly enough, business openings and closings.

Stephen: I guess crazy is as crazy does. But what does this mean for us and the residential market for upscale patio homes?

Richard: Good question - Bob tells me that most of his inquiries and sales are coming from people outside of the area. In fact, they're predominately from out-of-state and out of the region entirely. These people are looking for not only showcase, maintenance free homes but they are looking to live in areas that they have never experienced before. They're also looking to have several homes, usually a summer and winter residence, in an area where they can have all the amenities of a vacation community. The internet has made location less of an issue for them since many work out of their home and also do a lot of traveling. Also, many of them are semi-retired and economically well off enough to work when they want to work and where they want to work.

Stephen: Must be nice! But what does that mean for us and Bob's approach to marketing our patio homes?

Richard: I was just getting to that. Bob has done the usual things with our homes, multiple listings, video tours, and listings in real estate magazines. However, his agency is part of an international real estate brokerage firm and therefore our homes are in their database. This means that people using search engines like Google and Yahoo can find our listings by doing a search for real estate in our area. I'm sure you've used these sites yourself to check on our competition - you type in the area, the type of home you want, the price range, and in a flash a list of homes pop up which you can take a virtual tour in and read the fact sheet about each house. More importantly, Bob can track hits on our homes, read the cookies of people who have visited our sites, and therefore get a better idea as to who is interested in our homes - you've heard the term data mining, well that's what Bob is doing!

Stephen: And the results of this internet spying?

Richard: The proof is in the pudding - we've had more traffic and more inquiries about our homes in the last two weeks than we have had in the last three months. We have at least three interested buyers in our existing inventory, a real plus since we need to move these ASAP, and at least one buyer interested in a pre-construction sale. If we can land half of them that would be twice as many sales in a month than we are doing now.

Stephen: That's fine but I'll hold judgment on both Rhonda and Bob until they've been with us for awhile. They may be flashes in the pan and l'd hate us having to commit ourselves to exclusive contracts with these agents, even if only for six months. I, however, understand that they would not expend the effort on our behalf otherwise. Ok, let's move on to operations - anything I should know? 
Richard: Nothing new - as you already know we used to hire a firm to management our rental properties for a 10 percent rental fee but found it too expensive, given our negative cash flow. My wife Adrienne has taken on the task of keeping track of our rental properties, without salary I might add, and that seems to be working out fine since we have a better crop of renters. Any repairs needed on these homes are handled by our own subcontractors including James Kennison and therefore our repair costs are quite low as compared to when we were just in the rental business.

Stephen: Yes, I know that you and Adrienne are not drawing a salary and that is unacceptable to me. You guys put time and effort into the business and should get paid for that time. I know that you insist that we do not have the cash flow to pay both of you but there has to be some form of compensation we can give you. How are you ever going to retire from the college if we can't even afford to pay you a salary?

Richard: As I told you on numerous occasions, we'll work this all out when there is actually some money in the business to talk about! Right now I'm more worried about the slowdown in the business and how this will affect our subcontractors and our ability to get them to work in a timely fashion. Since we have no workers of our own, a good thing I might add from a liability perspective, we are entirely dependent upon them for work completion. However, as our work becomes a smaller percentage of their total work load, their loyalty and timeliness of work completion may also shrink.

Stephen: I guess this is an unavoidable situation. Anything else worth discussing?

Richard: Not at this time - let's take a break and think about what we've covered in these meetings and what this all means to our businesses. We need to assess our progress from when we first started our first business, and determine if we're any closer to reaching our original goal of financial independence and for me, early retirement.

As Stephen and Richard parted company, Richard wondered if five years from now he and Stephen would be having similar conversations about similar problems - that he would still be teaching while working the business and Stephen would still have to spend all of his time on research for the both of them in order to keep their academic integrity. There had to be a way off this vicious treadmill and he and Stephen had to figure out exactly how to do it, or certainly exhaust themselves trying. Richard couldn't help but ask himself if he and Stephen were dreaming the impossible dream or would their vision for themselves, their businesses, and their retirement come to fruition; only time would tell.

[Note: The Teaching Note for this case may be obtained by contacting Herbert Sherman@ herbert.sherman@liu.edu.] 
Exhibit 1

D \& H Management Balance Sheet, 5/31/06

ASSETS

May 31, 06

Current Assets

Checking/Savings

$1110 \cdot$ Checking - Wells Fargo

Total Checking/Savings

$\frac{-4,920.92}{-4,920.92}$

Other Current Assets

1220 - A/R - Key Property Mgmt

$1350 \cdot$ Mortgage Escrow

Total Other Current Assets

$1,470.00$

$16,443.11$

$17,913.11$

Total Current Assets

$12,992.19$

Fixed Assets

1500 - Leased Properties

$1501 \cdot 2703$ Marina Street

$190,693.56$

$1503 \cdot 2712$ Haven Court

$191,792.88$

$1504 \cdot 2515$ Waterfront

$176,155.55$

$1505 \cdot 2704$ Haven Court

$191,834.35$

$1506 \cdot 2700$ Haven Court

$185,630.37$

$1507 \cdot 2512$ Waterfront

$212,733.39$

$1508 \cdot 2606$ Waterfront

$191,780.05$

$1510 \cdot 2416$ Dock Drive

$194,957.21$

1512 - 3513 Poppi Avenue

$295,599.90$

1513 - 400 Sunset Beach Dr

$790,511.79$

$1514 \cdot 1523$ Willow Lane

$418,507.69$

$1516 \cdot 1515$ Willow Lane

$366,744.72$

$1517 \cdot 411$ Sunset Beach

Total 1500 - Leased Properties

$\frac{413,900.00}{3,820,841.46}$

1600 - Accumulated Depreciation

Total Fixed Assets

$\frac{-196,061.00}{3,624,780.46}$

TOTAL ASSETS

$3,637,772.65$

LIABILITIES \& EQUITY

Liabilities

Current Liabilities

Accounts Payable

2010 - Accounts Payable

Total Accounts Payable

$\frac{149.25}{149.25}$

Other Current Liabilities 
2200 - 4505 Property Mgmt-Nelson

$-5,013.97$

2210 - 4508 Property Mgmt-Adams

$-14,225.06$

2220 - 4513 Property Mgmt-Smith

2230 - 4509 Property Mgmt-Johnson

2300 - Security Deposits

2320 - N/P - D \& H Patio Homes

Total Other Current Liabilities

$-10,008.92$

$-11,910.73$

$9,800.00$

$-15,326.24$

$-46,535.67$

Total Current Liabilities

Long Term Liabilities

$$
2400 \cdot \text { N/P - Mortgages }
$$

$2401 \cdot$ N/P - 2703 Marina

2401.1 - N/P - 2703 Marina (2nd)

$2403 \cdot$ N/P - 2712 Haven Court

2403.1 - N/P - 2712 Haven (2nd)

$2404 \cdot$ N/P - 2515 Waterfront

2404.1 $\cdot$ N/P - 2515 Waterfront (2nd)

2405 - N/P - 2704 Haven Court

2405.1 - N/P - 2704 Haven (2nd)

$2406 \cdot$ N/P - 2700 Haven Court

$2407 \cdot$ N/P - 2512 Waterfront

2407.1 - N/P - 2512 Waterfront (2nd)

$2408 \cdot$ N/P - 2606 Waterfront

$2410 \cdot$ N/P - 2416 Dock Drive

$2412 \cdot$ N/P - 3513 Poppi

2412.1 - N/P - 3513 Poppi (2nd)

2413 - N/P - 400 Sunset Beach Dr

2413.1 - N/P - 400 Sunset Beach (2nd)

$2414 \cdot$ N/P - 1523 Willow Lane

2414.1 - N/P - 1523 Willow Lane (2nd)

$2416 \cdot$ N/P - 1515 Willow Lane

2416.1 - N/P - 1515 Willow Lane (2nd)

$2417 \cdot$ N/P - 411 Sunset Beach

2417.1 - N/P - 411 Sunset Beach (2nd)

Total $2400 \cdot$ N/P - Mortgages

$165,522.30$

$20,500.00$

$142,399.99$

$28,400.00$

$164,000.00$

$20,500.00$

$164,821.89$

$20,500.00$

$166,465.84$

$158,507.26$

$25,800.00$

$149,878.85$

$159,948.59$

$265,523.68$

$32,754.46$

$624,000.00$

$116,819.59$

$354,300.00$

$66,400.00$

$287,900.00$

$53,985.00$

$367,900.00$

$46,000.00$

$3,602,827.45$

2500 - N/P - Davis LOC (WF)

$10,831.61$

$2510 \cdot$ N/P - Hodgetts LOC (WF)

$12,505.80$

Total Long Term Liabilities

$3,626,164.86$

$3,579,629.19$

Total Liabilities

Equity

3100 - Davis Capital

3110 - Davis Cap Beginning Balance 


\author{
$3200 \cdot$ Hodgetts Capital \\ 3210 - Hodgetts Cap Beginning Balance \\ 3910 - Retained Earnings \\ Net Income \\ Total Equity
}

TOTAL LIABILITIES \& EQUITY
$85,332.85$

$193,887.89$

$-198,377.29$

$-21,930.17$

$58,143.46$

$3,637,772.65$ 
Exhibit 2

D \& H Management Income Statement, 5/31/06

\begin{tabular}{|c|c|}
\hline & $\begin{array}{c}\text { Jan - May } \\
06\end{array}$ \\
\hline \multicolumn{2}{|l|}{$\begin{array}{l}\text { Ordinary Income/Expense } \\
\text { Income }\end{array}$} \\
\hline $4100 \cdot$ Rental Income & $69,558.03$ \\
\hline Total Income & $69,558.03$ \\
\hline Gross Profit & $69,558.03$ \\
\hline \multicolumn{2}{|l|}{ Expense } \\
\hline \multicolumn{2}{|l|}{$6600 \cdot$ Rental Expenses } \\
\hline $6610 \cdot$ Advertising & 793.88 \\
\hline $6630 \cdot$ Cleaning/Janitorial & 868.00 \\
\hline $6650 \cdot$ Insurance & $3,512.18$ \\
\hline $6660 \cdot$ Interest Expense & $80,518.44$ \\
\hline $6670 \cdot$ Legal Fees & 12.00 \\
\hline $6700 \cdot$ Management Fee & $2,170.35$ \\
\hline 6750 - Repairs \& Maintenance & $6,452.34$ \\
\hline $6820 \cdot$ Property Taxes & $10,381.11$ \\
\hline $6900 \cdot$ Supplies & 298.41 \\
\hline 6970 - Utilities & $3,360.25$ \\
\hline Total $6600 \cdot$ Rental Expenses & $108,366.96$ \\
\hline $6060 \cdot$ Bank Service Charges & 74.00 \\
\hline $6310 \cdot$ Professional Fees & $2,565.75$ \\
\hline $6400 \cdot$ Travel & 934.95 \\
\hline Total Expense & $111,941.66$ \\
\hline Net Ordinary Income & $-42,383.63$ \\
\hline \multicolumn{2}{|l|}{ Other Income/Expense } \\
\hline \multicolumn{2}{|l|}{ Other Income } \\
\hline $7100 \cdot$ Gain/Loss on Sales & $20,453.46$ \\
\hline Total Other Income & $20,453.46$ \\
\hline Net Other Income & $20,453.46$ \\
\hline ome & $-21,930.17$ \\
\hline
\end{tabular}


Exhibit 3

D \& H Patio Balance Sheet, 5/31/06

ASSETS

Current Assets

Checking/Savings

1000 - Checking - Advantage Bank

1120 - Checking - Bank of Choice

1140 - Checking - New Frontier Bank

Total Checking/Savings

May 31, 06

Other Current Assets

$1250 \cdot N / R$-D \& H Management, LLC

$-15,326.24$

1270 - N/R - DRPH Investment Group LLC

50.00

$1400 \cdot$ WIP - Construction

$1,108,992.72$

$1410 \cdot$ Landscaping - Snowy Mountains

$55,895.42$

$1440 \cdot$ WIP-Construction Interest

$36,625.62$

1450 - Lots - Snowy Mountains

1460 - Lots - Florence

$1461 \cdot 3405$ San Mateo

$1462 \cdot 4517$ Tuscany St.

$1463 \cdot 3511$ San Mateo

$1464 \cdot 3507$ San Mateo

Total $1460 \cdot$ Lots - Florence

$1,386,086.19$

$61,887.95$

$63,814.97$

$70,801.14$

$74,441.14$

$270,945.20$

Total Other Current Assets

$2,843,268.91$

Total Current Assets

$2,822,936.69$

Fixed Assets

1520 - Computer \& Office Equipment

$2,338.88$

1530 - Machinery \& Equipment

$22,469.83$

1540 - Accumulated Depreciation

$-16,622.00$

1600 - Loan Fees

Total Fixed Assets

$8,064.52$

$16,251.23$

TOTAL ASSETS

2,839,187.92

LIABILITIES \& EQUITY

Liabilities

Current Liabilities

Accounts Payable

2010 - Accounts Payable

Total Accounts Payable

$\frac{182,644.30}{182,644.30}$

Credit Cards 
2050 - United Mileage Plus (**0929)

$1,395.79$

2170 - Capital One Visa (**9766)

$13,733.35$

$2080 \cdot$ Brand Source $(* * 3221)$

Total Credit Cards

$5,371.99$

$20,501.13$

Other Current Liabilities

2200 - Deferred Revenue

$2300 \cdot$ N/P - Stephen Hodgetts

$354,937.20$

$-2,629.96$

$2330 \cdot$ N/P - Richard Davis

$89,132.81$

$2400 \cdot$ N/P - Construction Loans

$2450 \cdot 2124$ 20th St Drawn Costs

Total Other Current Liabilities

$1,299,605.56$

$51,709.14$

$1,792,754.75$

Total Current Liabilities

$1,995,900.18$

Long Term Liabilities

2610 - N/P - Advantage Bank - SM Lots

$577,156.63$

$2700 \cdot$ N/P - Lots (3405)

$34,657.31$

$2710 \cdot$ N/P - Lots (4517)

$37,442.36$

$2720 \cdot$ N/P - Lots $(3511,3507)$

Total Long Term Liabilities

$93,201.32$

$742,457.62$

Total Liabilities

$2,738,357.80$

Equity

$3100 \cdot$ Owner's Capital

$3110 \cdot$ Investments - Hodgetts

3120 - Investments - Davis

Total $3100 \cdot$ Owner's Capital

$134,912.91$

$-109,702.69$

$25,210.22$

$3910 \cdot$ Retained Earnings

$1,073.20$

Net Income

Total Equity

$74,546.70$

$100,830.12$

TOTAL LIABILITIES \& EQUITY

2,839,187.92 
Exhibit 4

D \& H Patio Income Statement, 5/31/06

Ordinary Income/Expense

Income

$4110 \cdot$ Sales

Total Income

\begin{tabular}{c} 
Jan - May \\
06 \\
\hline
\end{tabular}

$\frac{1,721,128.05}{1,721,128.05}$

Cost of Goods Sold

$5110 \cdot$ Cost of Homes Sold

Total COGS

$\frac{1,510,650.65}{1,510,650.65}$

Gross Profit

$210,477.40$

Expense

$6020 \cdot$ Advertising
$6060 \cdot$ Bank Service Charges
$6100 \cdot$ Car/Truck Expense
$6101 \cdot$ Gas \& Oil
Total $6100 \cdot$ Car/Truck Expense

197.02

369.00

$1,003.22$

$6130 \cdot$ Cleaning/Janitorial

$1,847.00$

75.00

$6160 \cdot$ Dues and Subscriptions

$6,301.39$

$6200 \cdot$ Interest Expense

$1,313.43$

6201 . Finance Charge

$29,205.11$

6202 - Loan Interest

Total $6200 \cdot$ Interest Expense

$30,518.54$

6230 - Licenses and Permits

50.00

47.80

6240 - Miscellaneous

$1,259.02$

6570 - Professional Fees

$2,670.00$

$6571 \cdot$ Accounting

267.19

Total $6570 \cdot$ Professional Fees

$2,937.19$

6610 - Postage and Delivery

281.43

6620 - Promotion

$9,084.75$

$6650 \cdot$ Rent

$72,958.15$

878.00

$6670 \cdot$ Repairs \& Maintenance

460.83

$6700 \cdot$ Supplies

524.55

6900 - Travel \& Ent

80.24 
$6902 \cdot$ Meals

$2,056.74$

$6904 \cdot$ Hotels/Lodging

Total $6900 \cdot$ Travel \& Ent

493.37

$6920 \cdot$ Tools \& Machinery (under $\$ 500$ )

$2,630.35$

$6970 \cdot$ Utilities

Total Expense

$1,589.00$

$2,918.46$

$135,930.70$

Net Ordinary Income

$74,546.70$

Net Income

$74,546.70$ 